\title{
Prokaryotic Cell Component
}

National Cancer Institute

\section{Source}

National Cancer Institute. Prokaryotic Cell Component. NCI Thesaurus. Code C17711.

A structure or space in a prokaryotic cell. 